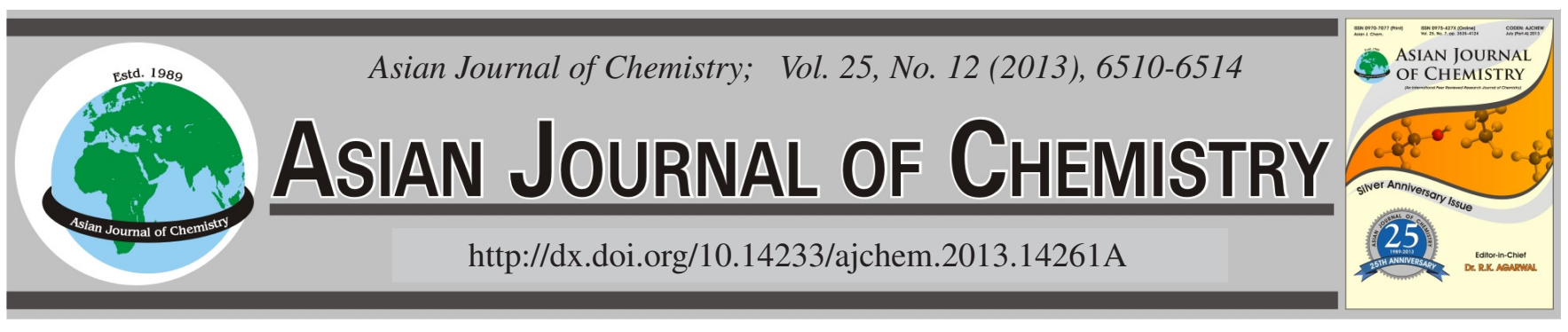

\title{
Study on the Reuse of a Waste Landfill from Physical and Chemical Properties and Biodegradability of Landfill Waste Assessment
}

\author{
JiNDO CHUNG* and KIRYUL PARK
}

Department of Environmental Engineering, Hoseo University, Asan city, Chung-nam 336-792, Republic of Korea

*Corresponding author: Fax: +82 41 5405394; E-mail: jdchung@ hoseo.edu

\begin{abstract}
This paper assessed the physico-chemical characteristics and biodegradability of wastes buried on Sindong landfill, Asan City, | Chungcheongnam-dowhose service life was about to end and conducted a basic study to reuse a landfill. There were three sampling spots on Sindong landfill, Asan city, Chooncheongnam-do. The spots were divided into three areas by terms of years for reclamation. Samples were collected both from upper and lower areas and their physicochemical characteristics were explored while an analysis of biodegradability assessment (AT4, BMP) was conducted. Based on the results, the contents of combustibles were very high. This result enables us to assume that the contents of vinyl and plastic materials of low decomposition speeds were high in the wastes previously introduced on Sindong landfill. Based on the results from analyses of the three components covering water, combustibles and lime, the highest level of water content was $43.06 \%$ in the lower area of W-1 while its lowest level was $25.38 \%$ in the upper area of W-2. Water contents were higher in the lower areas where samples were collected. It can be said that based on the characteristics of a sanitary landfill, there is an impact of shield skirts as leachate treatment facilities in the lower area of a landfill. Anaerobic (BMP TEST) biodegradability as one of the ways to assess biodegradability of wastes was around $20 \%$, which is lower than that of general wastes amounting to $52.8-78.3 \%$. Based on the results from aerotropic (AT4) assessment, the oxygen consumption in buried wastes was 5.44-19.12 mg $\mathrm{O}_{2} / \mathrm{g}$ dry matter. On all sample collection sites, the results were $25 \mathrm{mg} \mathrm{O}_{2} / \mathrm{g}$ dry matter or below, which is the standards for advance stabilization. The results from our analyses provided basic materials for the reuse of Sindong landfill. The basic materials will be able to contribute to finding ways to use and maintain a landfill with their service term ending soon and design processes for the reuse of Sindong landfill.
\end{abstract}

Key Words: Waste landfill, Biochemical methane potential, AT4, Biodegradability.

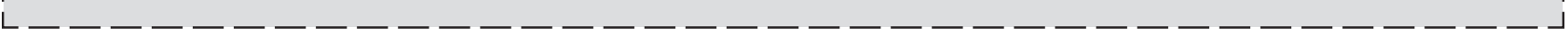

\section{INTRODUCTION}

Waste landfills can be divided into sanitary and unsanitary landfills depending on the installation and operation of environmental facilities such as waterproof facilities for leachate and leachate treatment facilities ${ }^{1}$. As for a sanitary landfill, the impact of the surrounding environment including underground water, especially, is not very significant. However, as for an unsanitary landfill, when it has been used or is being used, the introduction of leachate continuously generated will severely pollute the nearby underground water as well as the related surface water.

The Ministry of Environment divides the unsanitary landfill management into sorting and transfer techniques and stabilization techniques ${ }^{2,3}$. Sorting and transfer techniques are to excavate unsanitary landfills whose usage has been terminated, select combustibles or subjects of economic value and reclaim again. As for these techniques, even when the pollution of underground water is ceased, the recovery of the surrounding underground water system exposed to contaminants for a long time will not take place. The currently highlighted onsite stabilization techniques have a problem that contaminants will still be introduced to the surrounding underground system even when the stabilization of a landfill is continued. Additionally, as for unsanitary landfills, unplanned or design-absent construction leads to long-term generation of subsidence and pollution, resulting in great restrictions on the land use while the continued generation of bad smell and danger of explosion or fire necessitates a long period for sufficient stabilization, which is likely to lead to problems with early application. Also the small-scale and temporary reclamation makes it difficult to establish appropriate construction techniques and increases the construction costs. Hence, there is no methods for actual treatment techniques other than excavation, transfer and reclamation.

So this paper aims to provide a basic study on the reuse of a landfill based on assessment of the physiochemical characteristics and advance stabilization (BMP, AT4) of buried 
wastes on Sindong landfill, Asan City, Chungcheongnamdowhose term of use is about to expire. It also aims to present strategic directions to cope with rapid paradigm changes of landfills whose terms of use are about to end in the civilized society.

\section{EXPERIMENTAL}

Subject samples: Samples were collected from upper and lower areas of the three sites on Sindong landfill, Asan City, Chooncheongnam-do, divided based on the length of burial time. The equipments used for collecting samples include excavators and Auger cranes. Analyses of physiochemical characteristics and biodegradability of samples collected by site and location were conducted.

Analysis of physical components: As the most important material to assume the characteristics of buried wastes such as the types of buried wastes and calculation of caloric value, analyses of apparent density, physical composition and the three components covering water, combustibles and lime were conducted based on the standard wastes testing methods. The chemical component analysis covered chemical elements such as carbon, hydrogen, oxygen, sulfur and chlorine and the equipment used for this was the Automatic Elemental Analyzer.

Theoretical estimation of gases generated and accumulated gases: An elemental analysis of organic wastes that can be decomposed biologically was conducted to produce a chemical formula. And then, the following formula (Buswell's equation) was applied with an assumption that all organic matters should be converted to carbon dioxide and methane to calculate the total amount of digestion gases that might be generated $^{4,5}$.

$$
\begin{aligned}
\mathrm{C}_{\mathrm{n}} \mathrm{H}_{\mathrm{a}} \mathrm{O}_{\mathrm{b}} \mathrm{NCS}_{\mathrm{d}}+(\mathrm{n}-\mathrm{a} / 4-\mathrm{b} / 2+7 \mathrm{c} / 4+\mathrm{d} / 2) \mathrm{H}_{2} \mathrm{O} \longrightarrow \\
(\mathrm{n} / 2-\mathrm{a} / 8+\mathrm{b} / 4-3 \mathrm{c} / 8+\mathrm{d} / 4) \mathrm{CO}_{2}+ \\
(\mathrm{n} / 2+\mathrm{a} / 8-\mathrm{b} / 4-3 \mathrm{c} / 8-\mathrm{d} / 4) \mathrm{CH}_{4}+\mathrm{cNH}_{4}+\mathrm{dH}_{2} \mathrm{~S}
\end{aligned}
$$

This formula covers the relations between chemical composition of organic matters and methane transference number. The data from the sample's elemental analysis was substituted to calculate the theoretical amount of gases that could be generated. As for organic matters with higher mole contents such as carbon and hydrogen, the methane transference number will be assessed relatively higher while oxygen and nitrogen in chemical composition of organic matters tends to be highly related to the carbon dioxide fraction. The contents of $\mathrm{a}=\mathrm{C}, \mathrm{b}=\mathrm{H}, \mathrm{c}=\mathrm{O}$ and $\mathrm{d}=\mathrm{S}$ are $(\%) / 12,(\%) / 1,(\%) / 16$ and $(\%) / 32$, respectively.

Generally, as for the measurement of cumulative $\mathrm{CH}_{4}$, the amount of methane gases generated for each volatile solid matter of wastes introduced will be calculated and presented in $\mathrm{mL} \mathrm{CH}_{4} / \mathrm{g}$ VS.

\section{Production of methane gas:}

$$
\mathrm{V}_{\mathrm{CH}_{4}}-\mathrm{M}_{1}\left(\mathrm{~V}_{1}+\mathrm{V}_{0}\right)-\mathrm{M}_{0} \mathrm{~V}_{0}
$$

$\mathrm{V}_{\mathrm{CH}_{4}}$ : produced methane colume $(\mathrm{mL}) ; \mathrm{M}_{1}$ : methane content (\%) at sample time; $\mathrm{M}_{0}$ : methane content $(\%)$ at previous sampling time; $\mathrm{V}_{1}$ : biogas volume measured by syringe $(\mathrm{mL})$; $\mathrm{V}_{0}$ : gas phasc volume of the reactor $(\mathrm{mL})$

Cumulative methane gas: $\mathrm{V}_{\mathrm{CH}_{4}}\left[\mathrm{STP} \mathrm{L} / \mathrm{g} \mathrm{V}_{\mathrm{S}}\right]=$ $\mathrm{V}_{\mathrm{CH}_{4}}\left(\right.$ measured at $\left.35^{\circ}\right) \times\{273 /(273+35\} \times\{760-42.2) / 760\}$; 42.2 is saturation vapour pressure $(\mathrm{mmHg})$ at $35^{\circ} \mathrm{C}$.
Nutrient medium and seeding sludge: Microorganism media to be used in a biochemical methane potential (BMP) test were prepared according to the method of Shelton and Tiedje ${ }^{6}$. Firstly, $1 \mathrm{~N} \mathrm{NaOH}$ was prepared and $40 \mathrm{~g}$ of $\mathrm{NaOH}$ was melted in distilled water. It was placed into a 1,000 mL volume flask until it reached the marked line. And then, $1 \mathrm{~N}$ $\mathrm{HCl}$ prepared - $\mathrm{HCl} 36.5 \mathrm{~g}$ was added in distilled water. It was placed into a $1,000 \mathrm{~mL}$ volume flask until it reached the marked line. The components and quantities used for the preparation of nutrient media are as presented in Table-1. The phosphate buffer solution and inorganic nutrients were diluted 10 times until the volume reached $1,000 \mathrm{~mL}$ while microelements were concentrated 1,000 times. The sample won't be completely melted when making a medium. So while it is being mixed, the sample shall be collected with a pipette to make a medium. The phosphate buffer solution and $100 \mathrm{~mL}$ of inorganic nutrients were mixed with $1 \mathrm{~mL}$ of microelements. It was placed in a $1,000 \mathrm{~mL}$ volume flask until the marked line was reached along with distilled water. And then, a sterilization medium was placed in a sample vial. This was pressurized and sterilized for ten minutes in a sterilizer. As for the seeding sludge for injecting anaerobic microorganisms, the remainder of the material collected from an anaerobic bath at Asan Environment Affairs Agency and filtered several times.

\begin{tabular}{ccc}
\multicolumn{3}{c}{ TABLE-1 } \\
COMPONENTS AND QUANTITIES USED FOR THE \\
PREPARATION OF NUTRIENT MEDIA \\
\hline \multicolumn{2}{c}{ Compound } & Concentration $(\mathrm{g} / \mathrm{L})$ \\
\hline \multirow{2}{*}{ Phosphate buffer } & $\mathrm{KH}_{2} \mathrm{PO}_{4}$ & 0.27 \\
& $\mathrm{~K}_{2} \mathrm{HPO}_{4}$ & 0.35 \\
\hline \multirow{3}{*}{ Mineral salts } & $\mathrm{NH}_{4} \mathrm{Cl}$ & 0.53 \\
& $\mathrm{CaCl}_{2} \cdot 2 \mathrm{H}_{2} \mathrm{O}$ & 0.075 \\
& $\mathrm{MgCl}_{2} \cdot 6 \mathrm{H}_{2} \mathrm{O}$ & 0.1 \\
& $\mathrm{FeCl}_{2} \cdot 4 \mathrm{H}_{2} \mathrm{O}$ & 0.02 \\
\hline \multirow{5}{*}{ Trace metals } & $\mathrm{MnCl}_{2} \cdot 4 \mathrm{H}_{2} \mathrm{O}$ & 0.0005 \\
& $\mathrm{H}_{3} \mathrm{BO}_{3}$ & 0.00005 \\
& $\mathrm{ZnCl}_{2}$ & 0.00005 \\
& $\mathrm{CuCl}_{2}$ & 0.00003 \\
& $\mathrm{NaMoO}_{4} \cdot 2 \mathrm{H}_{2} \mathrm{O}$ & 0.00001 \\
& $\mathrm{CoCl}_{2} \cdot 6 \mathrm{H}_{2} \mathrm{O}$ & 0.0005 \\
& $\mathrm{NiCl}_{2} \cdot 6 \mathrm{H}_{2} \mathrm{O}$ & 0.00005 \\
& $\mathrm{Na}_{2} \mathrm{SeO}_{3}$ & 0.00005 \\
\hline
\end{tabular}

Assessment of wastes biodegradability (Anaerobic BMP TEST): In the BMP test, a serum bottle was used to inject necessary anaerobic microorganisms and nutrients into a bottle. While the optimum conditions such as temperature and $\mathrm{pH}$ were maintained, the amount of gas generated and its composition were identified. Samples of buried wastes were collected from sites divided into w-1 (upper, lower), w-2 (upper, lower) and w-3 (upper, lower) (within $2 \mathrm{~m}$ for upper areas and $7 \mathrm{~m}$ for lower areas). They were dried at the temperature of $105^{\circ} \mathrm{C}$ (autoclave) and exposed to coldness before reducing them to powder as small as $10 \mathrm{~mm}$ or smaller.

In order to remove oxygen in a sample vial, nitrogen gas was injected to reach an anaerobic state and then microorganism media and sludges were injected at the rate of 1:10. First, $300 \mathrm{~mL}$ of media was placed before filling nitrogen gas and placing $30 \mathrm{~mL}$ of seeding sludges. Again, nitrogen gas was 
filled before placing a substrate (1.5 g VS/L, sample). In order to make $\mathrm{pH}$ level 7 after filling nitrogen gas, $\mathrm{pH}$ was adjusted with $1 \mathrm{~N} \mathrm{NaOH}$ and $1 \mathrm{~N} \mathrm{HCl}$ before filling nitrogen gas again. And then, bicarbonate was placed and capping was applied to secure sufficient alkalinity, which is to suppress the reduction of $\mathrm{pH}$. After capping, a three-way cock was used to place a glass syringe into a sample vial. The incubator temperature was set at $35^{\circ} \mathrm{C}$ and a sample vial was placed for culturing. As for the gas produced, the amount was checked with a glass syringe connected to a three-way cock. As for the gas analysis, a GC syringe was used to collect gases of about $50 \mu \mathrm{L}$ and direct injection into GC (GC : Agilent 7890 A GC Chemstation) was conducted. The analytic conditions for GC are as presented in Table-2. The calibration curve was prepared on each analysis using 2.5, 5 and $10 \% \mathrm{CH}_{4}$ standard gases.

TABLE-2

\section{ANALYTIC CONDITIONS FOR GC}

\begin{tabular}{ll}
\hline Component & Analysis method \\
\hline Gas chromatography & Agilent 7890 A GC Chemstation \\
Detector & FID (Flame Ionization Detector) \\
Columns & HP Capillary Columns $30 \mathrm{~m}$ \\
Temperature & $250^{\circ} \mathrm{C}$ \\
Pressure & $10.3 \mathrm{pa}$ \\
Oven temperature & $30^{\circ} \mathrm{C}$ \\
Quantity & $50 \mu \mathrm{L}$ \\
\hline
\end{tabular}

Wastes biodegradability assessment (aerotropic AT4 TEST): The principle of AT4 is to measure the amount of oxygen reduced from pressure lowered based on the soda lime absorption of carbon dioxide generated from aerotropic microorganisms. Based on this principle, Oxitop Control OC110 produced by Germany's WTW was used. The calculation was based on the respiratory quotient formula provided by WTW ${ }^{7}$.

The collected samples were dried at $105^{\circ} \mathrm{C}$ and powered up to $10 \mathrm{~mm}$ or below. As for the $40 \mathrm{~g}$ of samples in an analytic bottle $(1000 \mathrm{~mL})$, water was saturated up to $50-70 \%$ of the maximum water holding capacity (WHC). As an absorber, $\mathrm{NaOH}$ was placed and cultured in an incubator at $20^{\circ} \mathrm{C}$. Carbon dioxide generated from aerotropic microorganisms for four days (96 h) was absorbed with $\mathrm{NaOH}$ to calculate the rate of oxygen consumption due to the pressure difference in a bottle ${ }^{8}$.

\section{RESULTS AND DISCUSSION}

\section{Physico-chemical properties of wastes}

Physical composition and the three components covering water, combustibles and lime: The material covers the measurement of apparent density using a $20 \mathrm{~L}$ container for samples collected from three sites (upper and lower). Apparent density of wastes differ by compositional elements, moisture, forms and sizes of wastes as well as sources of generation and seasons.

Table- 3 suggests that density is greater in lower areas of $\mathrm{W}-1, \mathrm{~W}-2$ and $\mathrm{W}-3$ while average apparent density is $0.53 \mathrm{~kg} /$ L. Table-4 shows physical composition. Among all contents of combustibles, the amount of vinyl and plastic materials was the highest, followed by paper materials. Plastic materials have the greatest impact of carbon contents in elemental composition ${ }^{9}$. Table- 5 shows that plastic materials have higher carbon contents as their decomposition is difficult despite a long period of time of burial. The contents of food are much lower than those in general wastes (20-30\%) while there are no food materials in the lower areas of $\mathrm{W}-2$ and $\mathrm{W}-3$. This means that decomposition of food is much faster than that of other organic matters. Also, contents of combustibles are very high, enabling us to assume that the contents of vinyl and plastic materials whose decomposition is slow in the properties of the existing wastes buried in Sa landfill. Table-6 shows the results from analyses of the three components covering water, combustibles and lime. The water content was $43.06 \%$, which is the highest result, in the lower area of $\mathrm{W}-1$ while it was lowest at $25.38 \%$ in the upper area of W-2. By area of sample collection, water contents were higher in lower areas than upper ones, which means that based on the characteristics of a sanitary landfill, there was an impact of shield skirts as leachate treatment facilities in the lower area of the landfill. The higher amount of combustibles in this landfill than in others may have come from the sample collection method. For this test, excavators and Auger cranes were used to collect samples. Hence, the wastes buried could be evenly collected. Still, using Auger cranes only is unlikely to properly collect wastes buried and a lot of cover materials will be accompanied. This part necessitates clear standards for sample collection.

TABLE-3

COMPARISON OF DENSITY CHARACTERISTICS OF EXCAVATED WASTE IN S LANDFILL

\begin{tabular}{lccccccc}
\hline & W-1 (upper) & W-1 (lower) & W-2 (upper) & W-2 (lower) & W-3 (upper) & W-3 (lower) & Average \\
\hline Bulk density $(\mathrm{kg} / \mathrm{L})$ & 0.459 & 0.594 & 0.423 & 0.514 & 0.542 & 0.663 & 0.53 \\
\hline
\end{tabular}

TABLE-4

COMPARISON OF PHYSICAL CHARACTERISTICS OF EXCAVATED WASTE IN S LANDFILL

\begin{tabular}{cccccccccccc}
\hline & Food & Paper & Wood & Plastic & Rubber/Leather & Fiber & Metal & Glass & Sand & Others & Total \\
\hline W-1 (upper) & 2.24 & 15.12 & 1.44 & 40.03 & 0.97 & 2.64 & 1.02 & 4.72 & 26.73 & 5.10 & 100 \\
W-1 (lower) & 0.51 & 7.42 & 1.52 & 40.40 & 0.88 & 7.55 & 4.67 & 5.62 & 26.78 & 4.64 & 100 \\
W-2 (upper) & 0.57 & 13.89 & 1.74 & 38.26 & 0.61 & 6.39 & 3.73 & 3.36 & 27.41 & 4.04 & 100 \\
W-2 (lower) & 0 & 0.74 & 1.14 & 45.22 & 0.87 & 16.42 & 9.34 & 3.32 & 18.33 & 4.62 & 100 \\
W-3 (upper) & 2.15 & 5.48 & 0.76 & 24.15 & 0.18 & 0.33 & 1.07 & 2.22 & 46.93 & 16.75 & 100 \\
W-3 (lower) & 0 & 1.31 & 2.45 & 19.54 & 0.83 & 4.33 & 3.72 & 1.16 & 49.44 & 17.20 & 100 \\
Average & 0.91 & 7.33 & 1.51 & 34.60 & 0.72 & 6.28 & 3.92 & 3.40 & 32.60 & 8.72 & 100 \\
\hline
\end{tabular}


Vol. 25, No. 12 (2013) Reuse of a Waste Landfill from Physico-chemical Properties and Biodegradability of Landfill Waste Assessment 6513

\begin{tabular}{cccccccc}
\hline & \multicolumn{7}{c}{ TABLE-5 } \\
& \multicolumn{7}{c}{ COMPARISON OF CHEMICAL CHARACTERISTICS OF EXCAVATED WASTE IN S LANDFILL } \\
\hline & \multicolumn{7}{c}{ Chemical composition (weight ratio, \%) } \\
\cline { 2 - 8 } & $\mathrm{C}$ & $\mathrm{H}$ & $\mathrm{O}$ & $\mathrm{N}$ & $\mathrm{S}$ & $\mathrm{Cl}$ & Ash \\
\hline W-1 (upper) & 28.73 & 2.77 & 13.88 & 0.78 & 0.12 & 0.45 & 53.27 \\
W-1 (lower) & 21.04 & 3.07 & 22.15 & 0.72 & 0.02 & 0.60 & 52.40 \\
W-2 (upper) & 37.48 & 3.89 & 9.48 & 2.67 & 0.02 & 0.40 & 46.06 \\
W-2 (lower) & 9.86 & 1.53 & 7.38 & 0.34 & 0.03 & 1.15 & 79.71 \\
W-3 (upper) & 16.91 & 3.18 & 3.86 & 0.12 & 0.00 & 0.07 & 75.85 \\
W-3 (lower) & 14.34 & 2.36 & 4.90 & 0.22 & 0.01 & 0.14 & 78.04 \\
Average & 21.39 & 2.80 & 10.28 & 0.81 & 0.03 & 0.47 & 64.22 \\
\hline
\end{tabular}

\begin{tabular}{|c|c|c|c|c|}
\hline \multicolumn{5}{|c|}{$\begin{array}{c}\text { TABLE-6 } \\
\text { THREE COMPONENT ANALYSIS FOR EXCAVATED } \\
\text { WASTE IN S LANDFILL (Unit: wt \%) }\end{array}$} \\
\hline & Moisture & Combustible & Ash & Total \\
\hline W-1 (upper) & 30.68 & 34.97 & 34.35 & 100 \\
\hline W-1 (lower) & 43.06 & 28.57 & 28.37 & 100 \\
\hline W-2 (upper) & 25.38 & 50.65 & 23.97 & 100 \\
\hline W-2 (lower) & 32.96 & 15.22 & 51.83 & 100 \\
\hline W-3 (upper) & 27.07 & 29.42 & 43.51 & 100 \\
\hline W-3 (lower) & 27.36 & 19.06 & 53.58 & 100 \\
\hline Average & 31.09 & 29.65 & 39.27 & 100 \\
\hline
\end{tabular}

\section{Result from wastes biodegradability analyses}

Biochemical methane potential test: Table- 7 shows that biodegradability of buried wastes is as low as $20 \%$ overall. Especially, as for the upper area of W-2, biodegradability was $4.41 \%$. This may have come from much decomposition of organic materials due to reclamation. Fig. 1 shows the generation of methane gas, which means that organic matters of buried wastes have not yet been stabilized. This means that stabilization techniques for the reuse of a landfill shall take place in advance. Generally, when biodegradability is 5-7 \% or below, decomposition of organic matters can be understood to have been completed but there are no clear standards.

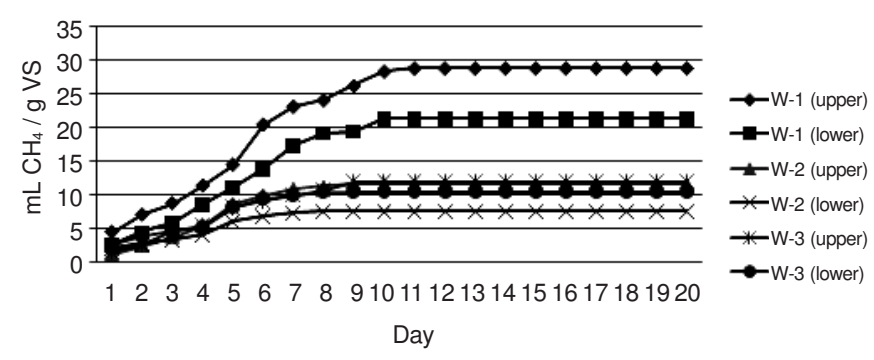

Fig. 1. Cumulative methane production for excavated

AT4 test: Table- 8 shows the results from the AT4 analysis as a method of assessing biodegradability under aerotropic conditions. The oxygen consumption of buried wastes was 5.44-19.12 $\mathrm{mg} \mathrm{O}_{2} / \mathrm{g}$ dry matter while that in the area below $\mathrm{W}-1$ was $19.12 \mathrm{mg} \mathrm{O}_{2} / \mathrm{g}$ dry matter, which is the highest amount among the results. This may come from, just like in a BMP test, the impact of sample homogeneity and contents of organic matters. The result in the upper area of W-1 was $10.25 \mathrm{mg} \mathrm{O}_{2} /$ $\mathrm{g}$ dry matter. The result may have come from the reduced upper ground temperature in the winter and lowered activities of microorganisms. As for the measurement of the remaining three sites, the lower area of W-2 was $16.88 \mathrm{mg} \mathrm{O} / 2$ g dry matter and the upper area of W-3 was $5.4486 \mathrm{mg} \mathrm{O} / \mathrm{g}$ dry matter while the lower area of W-3 was $7.6921 \mathrm{mg} \mathrm{O} / \mathrm{g}$ dry matter. All the sample collection sites resulted in $25 \mathrm{mg} \mathrm{O} / \mathrm{g}$ dry matter or below, the standard for assessment of advance stabilization ${ }^{10}$.

As for the overall trends in data, the oxygen consumption of buried wastes with shorter periods of burial is higher while that in lower areas, rather than upper ones, resulted in higher oxygen consumption. This may have come from factors such as the reduction in the ground surface temperature and activities of microorganisms in the winter, contents of organic matters and homogeneity ${ }^{11,12}$.

\section{Conclusion}

This paper presented a basic study on the reuse of waste landfills as well as the directions for reusing landfills based on analyses of the physical and chemical characteristics of wastes and biodegradability assessment. The test produced the following analytic results.

(1) Based on the results from analyses of physico-chemical characteristics, the contents of combustibles (about 60\%) were very high compared to those of the existing landfills (about $30 \%$ ). Based on the results from analyses of the three components covering water, combustibles and lime, water contents were higher in lower, than upper, areas on each site. This may have come from the characteristics of a sanitary landfill while the decrease of combustibles and the increase of lime can be attributed to decomposition of organic matters via microorganisms.

TABLE-7

THREE COMPONENT ANALYSIS FOR EXCAVATED WASTE IN S LANDFILL (Unit: wt \%)

\begin{tabular}{ccccccc}
\hline & W-1 (upper) & W-1 (lower) & W-2 (upper) & W-2 (lower) & W-3 (upper) & W-3 (lower) \\
\hline Cumulative gas $\left(\mathrm{mL} \mathrm{CH}_{4} / \mathrm{g}\right.$ VS) & 28.86 & 21.36 & 11.68 & 7.65 & 11.98 & 10.53 \\
Biodegradability (\%) & 17.22 & 20.93 & 4.41 & 13.25 & 10.89 & 10.28 \\
\hline
\end{tabular}

TABLE-8

CUMULATIVE $\mathrm{O}_{2}$ UPTAKE (AT4) OF WASTE IN S LANDFILL (Unit: $\mathrm{mg} \mathrm{O}_{2} / \mathrm{g}$ DM)

\begin{tabular}{cccccccc}
\hline & W-1 (upper) & W-1 (lower) & W-2 (upper) & W-2 (lower) & W-3 (upper) & W-3 (lower) \\
\hline Waste & 10.25 & 19.12 & 11.43 & 16.88 & 5.44 & 7.69 \\
\hline
\end{tabular}


(2) Biodegradability of anaerobic (BMP TEST) buried wastes was about $20 \%$. The generation of gases in samples stopped after about 10 days. Based on the results from aerotropic (AT4 TEST) assessment, oxygen consumption of buried wastes was $5.44-19.12 \mathrm{mg} \mathrm{O}_{2} / \mathrm{g}$ dry matter. In all sample-collection area, the amount was $25 \mathrm{mg} \mathrm{O} / \mathrm{g}$ dry matter or below, which is the standard for assessment of advance stabilization.

(3) As for more desirable treatment, combustibles on Sindong landfill, Asan City, Chungcheongnam-docan be dried and incinerated while non-combustibles can be re-buried. The selected landfill waste soils may be reused after their contents of organic foreign matters have been lowered than $1 \%$ via the secondary selection through washing or wind power.

This study helped us to secure a basic material on the reuse of Sindong landfill, Asan City, Chooncheongnam-do. This basic material will contribute to the future treatment and processing design for the reuse of Sindong landfill as well as establishing the methods to use and maintain landfills whose terms of use are about to end.

\section{ACKNOWLEDGEMENTS}

This work was supported by the Human Resources Development of the Korea Insitute of Energy Technology Evaluation and Planning (KETEP) grant funded by the Korea Government Ministry of Knowledge Economy (No. 20114010203130).

\section{REFERENCES}

1. Korea Environment Corporation, A Study on Methods of Establishment of Maintenance Guidelines for Landfills with Terminated Terms of Use by Type and Improvement of Maintenance Projects (2002).

2. Ministry of Environment and Forcebel Company, Techniques for Reduction, Reuse and Management of Wastes/Development of a Highly Efficient System to Select and Reuse Landfill Wastes (2006).

3. Kim Dong-oh, A Study on Methods of Maintenance of Unsanitary Landfills with Terminated Terms of Use via Sorting and Transfer, Hanyang University (2008).

4. J.M. Owens and D.P. Chynoweth, Water. Sci. Technol., 27, 1 (1993).

5. W.P. Owen, D.C. Stuckey, J.B. Healy Jr., L.Y. Young and P.L. McCarty, Water Res., 13, 485 (1979).

6. D.R. Shelton and J.M. Tiedje, Appl. Environ. Microbiol., 47, 850 (1984).

7. WTW: Respiration with Oxitop? Contro OC110, http:www.wtw.de/ en/products/lab/bodrespiration/depletionrespiration-oxitopr-control-oc110

8. R. Cossu and R. Raga, Waste Manag., 28, 381 (2008).

9. J.-D. Jeong, J.-W. Kim and J.-M. Han, J. Korea Soc. Waste Manag., 23, 344 (2006).

10. A Guideline for Maintenance in the Alternating Use of Landfills, Ministry of Environment (2010).

11. S.-R. Jeong, A Study on the Applicability of Oxygen Consumption Index for Assessment of Stabilization of Waste Landfills, Anyang University, Korea (2008).

12. S.-H. Song, A Study on the Usability of Biodegradability as an Index to Assess Stabilization of Buried Wastes, Anyang University, Korea (2005). 